\title{
THE CHILD NEGLECT AS A SOCIO-PSYCHOLOGICAL PROBLEM
}

\section{Mitina S. V.}

\section{INTRODUCTION}

The problem of the child neglect, which arose at the end XX century in our society, remains relevant for Ukraine at the present time. This is primarily due to the political and economic crisis in which Ukrainian society is located, military actions in the east of the country, destabilization of social life, internal migration, which led to an increase in the number of families who are in difficult life situations and cannot provide support for their children. These factors lead to the proliferation of child neglect and the to increase the number of minors with deviant behavior.

It should be noted that the problem of child neglect is interdisciplinary and studied by different specialists. In the scientific literature reveals a legal (V.O. Bolotova, I.V. Gorobets, N. Guivan, M.M. Gurenko, L. Kryvachuk, L.L. Tikhonenko) and socio-pedagogical aspects (G.M. BevZ, L.S. Volinets, I. Zvereva, A.Y. Kapska, N.M. Komarova G.M. Laktionova, V.M. Orzhehovska, etc.) problems of child neglect. In psychology, the relationship between the phenomenon of neglect and deviant behavior, its influence on the deformation of the personality and interpersonal relations is revealed (N.Yu. Maksimova, S.V. Mitina, I.V. Pesha, R.M. Tkach, Yu.M. Udovenko, T.A. Yurchenko etc.). However, there are not enough works devoted to the socio-psychological aspect of the study of the phenomenon of neglect of children and teenagers, a systematic analysis of the social and psychological prerequisites of the occurrence of this phenomenon. Meanwhile, taking into account socio-psychological factors would allow to apply a differentiated approach to providing psychological assistance to them and to determine the optimal forms of their livelihood in the process of re-socialization of neglected teenagers.

\section{Analysis of the concept and structure of child's neglect}

Regarding the category of neglect children, different terms are used in the literature: «homeless», «street children». According to the UNICEF 
definition, "street children are minors for whom the street has become a permanent place of stay". In a narrow sense, the notion "street children» is synonymous with the notion "homeless children" - "these are children and teenagers under the age of 17 , for whom the street is the main social environment and who are deprived of their permanent residence. From other children, who are most of the time on the street they are distinguished by the need to find a means of livelihood, so they actually lose the status of children, and become members of informal street gangs, along with marginalized"1.

In Ukraine, the concept of «street children» unites two other concepts: "homeless children" and "neglect children". In accordance with the Law of Ukraine "On the Protection of Childhood", homeless are children who were abandoned by their parents, left their own families or children's institutions where they were brought up, and do not have a specific place of residence ${ }^{2}$.

Accordingly, of the child neglect is the weakening or lack of supervision of the child by the parents. Consequently, the concept of «child neglect» is a broader concept than «street children»-a child who is deprived of parental care but lives at home. The first indicator of the neglect of children is the lack of care, positive influence on the part of parents, insufficient control over the behavior and activities of children. The extreme manifestation of neglect - "homelessness", is legally defined as the special social condition of a minor, which is characterized by:

a) lack of domicile (homelessness);

b) rupture of relations with parents (persons who replace them);

c) alienation from all institutions of socialization (family, educational and other institutions);

d) the lack of socially useful work.

V.M. Orzhehovska, notes that homelessness «like a long illness, goes through several stages of its development.» The initial phase of this social disease is neglect, and the final stage, which is on the verge of irreversibility, is homelessness, which determines the position of the minor himself, his peculiar social status, which he accepts on his own will or due

\footnotetext{
${ }^{1}$ Реалізація конвенції ООН права дитини в Україні: досягнення, проблеми, перспективи (за період 2009-2016 р.р.). Державна доповідь про становище дітей в Украӥні. Київ: Міністерство соціальної політики України, 2016. С. 24.

2 Про забезпечення організаційно-правових умов соціального захисту дітей-сиріт та дітей, позбавлених батьківського піклування. Закон України (зі змінами від 08.02.2018 року) Відомості Верховної Ради України. 2005. № 6. С. 147.
} 
to some circumstances. At the same time, neglect can be either the end stage of the social process, that is, the result of the transition from the "normal" state to the neglected state, or intermediate, that is, one of the stages of personality de-socialization and the transition to the state of homelessness, which is characterized by a complete separation of the minor from the family and is connected loss of permanent residence and occupation $^{3}$.

In our opinion, it is necessary to distinguish between children with partial and complete neglect. Children with partial neglect are children from families in which parents spend all day at work, which is why the child is deprived of adult control and stays at home after school. Partial neglect does not always lead to negative consequences: if children can take care of themselves after school, and most importantly, they maintain an emotional connection with their parents. Complete neglect regarding children is observed in all antisocial families. The lack of social assistance and psychological support for the child with the loss of parents, also often leads him to neglected status and further homeless ${ }^{4}$.

The concept of "neglect" is interpreted primarily from the position of a sociological approach as a social phenomenon; at the same time attention is focused on the social environment, the social conditions in which the child is. N. Komarova identifies nine groups of neglected children based on the degree of family distress and the child's time on the street from extremely negative, when children have no family and live permanently on the street, up to the group of children who live at home, have a family, but spend most on the street ${ }^{5}$.

F. Mustaeva takes as a criterion for classification the motivation of leaving a teenager from home. External motivation occurs when a teenager runs away from home due to the social disadvantage of the family. Internal motivation to leave home is observed in adolescents, who, due to their psychological characteristics, are prone to vagrancy and other types of deviant behavior ${ }^{6}$.

\footnotetext{
${ }^{3}$ Оржеховська В.М. Дитяча бездоглядність та безпритульність: історія, проблеми, пошуки: навч. посібник. Київ: Логос, 2004. 172 с.

Мітіна С.В. Соціальні чинники бездоглядності підлітків. Вісник Київського національного університету імені Тараса Шевченка Київ, 2013. № 1(7). С. 74-77.

Главник О., Комарова Н. Діти вулиці: хто вони і як їм допомогти. Київ: Главник, 2006. 112 с.

6 Мустаева Ф.А. Основы профилактики безнадзорности и беспризорности несовершеннолетних. Москва, 2003. 456 с.
} 
Summarizing the positions of different authors, as well as the results of our research, the following varieties of neglected teenagers can be identified:

- teenagers who lost their parents and, due to the lack of surgical intervention of the guardianship bodies, were recently found on the street;

- teenagers-runaway from boarding schools;

- teenagers who have a family, but due to family problems spend most of the day on the street;

- teenagers, who are permanent residents in the street as a result of a conscious rejection of the situation of family trouble;

- teenagers from socially well-off families who run away from home as a result of a conflict with their parents;

- teenagers with patoharakterologichnimi features that leads to uncontrolled behavior.

Consequently, in the category of neglected teenagers can get both from disadvantaged, and external well-off families, as well as children who do not have a family. The neglected can be one of the stages of personality desocialization and the transition to the state of homelessness, which is characterized by complete separation of the minor from the family and is connected to the loss of permanent residence

\section{Factors of the child's neglect}

The analysis of the literature on this problem allows us to identify two groups of factors for the increase in the number of neglect children at the present stage of development of society. These are the factors associated with the macrosocium: political, socio-economic, social and legal, and the causes caused by the microsocium: socio-pedagogical, sociopsychological, medical-psychological.

The global political factors of increasing the number of neglect children is the dramatic change in the functioning of the political system of Ukraine. The system of values has changed, the moral and ethical guidelines that existed in Soviet times are neglected by society, but others are still inefficient. A society of anomia described by E. Durkheim arose in the society, which gives rise to different types of deviant behavior, and in particular leads to an increase in child neglect. In addition, in today's difficult political conditions, the number of neglect and homeless children 
has increased significantly, due to the problem of relocating a significant number of families with children from Donetsk and Lugansk regions.

Socioeconomic factors include factors that for a long time violate life and deform the lives of people. Military operations in the east of the country led to a noticeable increase in the number of families who found themselves in a difficult life situation. According to sociological studies, about $70 \%$ of families self-identify their level of material status "below average"; the number of families who solve their material problems through the use of child labor has increased. The low level of social and legal protection of the institution of family and children leads to the economic exploitation by adults of child labor, weakening the responsibility of parents for the maintenance and upbringing of children. There is no sufficiently clear legal mechanism for the prevention of child neglect ${ }^{7}$.

Socio-psychological factors are connected with the moral and psychological crisis of society; with the crisis of the family institution, an increase in the number of divorces, single-parent families, aggravation of family conflicts, violence against children. The inability of parents to adapt to the realities of life, material distress leads to a deterioration in the psychological climate of the family, manifestations of deviant behavior of adults. One of the main reasons for the neglect of children is the alcoholism of parents. Due to the anti-social way of life, failure to parental responsibilities for the maintenance and education of children are deprived of parental rights, thereby increasing the number of children of social orphans. It should be noted that of more than 70 thousand orphans, less than 30\% are biological orphans. The rest are children who became orphans with living parents, thus the problem of child neglect is inextricably linked with the problem of social orphanhood ${ }^{8}$.

The socio-pedagogical factors for the increase in the number of street children is the crisis of the institute of education, the decline in the level of employment among children and teenagers after school hours. Out-ofschool activities during after-hours are curtailed, the number of different types of studios and clubs in schools and out-of-school institutions has

\footnotetext{
7 Горобець I. В. Механізми державного управління у сфері протидії дитячій безпритульності та бездоглядності в Україні: автореф. дис. на здобуття наук. ступеня канд. держ. упр.: 25.00.02 “Механізми державного управління”. Івано-Франківськ, 2012. С. 13.

8 Захист дітей, які потребують особливої уваги суспільства [Електронний ресурс] : статистичний збірник за 2017 рік / Державна служба статистики України ; [відп. за вип. О. О. Кармазіна]. Київ: ДССУ, $2018.77 \mathrm{c}$.
} 
sharply decreased. All of these factors affect the marginalization of teenagers and increase the likelihood of their going out.

Medical and psychological factors are associated with an increase in the number of children with psychosomatic and neurotic anomalies, character accentuation, and the presence of genetic predisposition. The spread of alcoholism and drug addiction among adults leads to an increase in genetically determined mental illness of children.

One of the main causes of child neglect at the present stage is of family troubles. A. Kapska notes the causes of socio-economic and moral and psychological, which lead to a deterioration of the child's position in the family and deprivation of parental care and guardianship. Socioeconomic factors is unemployment, the lack of permanent housing and places of work, or leaving their parents on incomes for abroad, with the result that children are neglected for a long time ${ }^{9}$. According to statistics in Ukraine in 2018 year, out of the number of economically active persons, $9.1 \%$ of women and $10.1 \%$ of men remained without work. In the case of long-term unemployment, the stressful state of the parents can turn into depression, lead to a loss of interest in life and marginalization.

Foreign scientists suggest the relationship between poverty, the social situation of parents and the child's propensity for deviant behavior. E. Durkheim noted that poverty is one of the main reasons, which predetermines the neglect of children. According to K. Bartol, upbringing deficiencies most often affect teenagers from families with low material income and the offenses of these children are the result of the negative experience they receive in the family ${ }^{10}$.

However, in the opinion, T.A. Yurchenko's financial distress of the family is an important, but not the decisive factor in the departure of children from the family. This requires a combination of interrelated factors: poverty, parental unemployment, family conflict, low educational level, parental asociality, and other reasons ${ }^{11}$.

A. Kapska notes that besides socio-economic reasons, there are still morally psychological factors that lead to the breakup of families, although they are also a consequence of the socio-economic and spiritual crisis. There are two types of family deformation: structural, associated with a violation of

\footnotetext{
${ }^{9}$ Капська А.Й. Організація і технології соціальної роботи з дітьми вулиці. Київ: Інтернаціональний Союз. Ліга соціальних працівників України, 2004. 260 с.

${ }^{10}$ Бартол К. Психология криминального поведения. СПб.: прайм-ЕВРОЗНАК, 2004. 352 с.

11 Юрченко Т.А. Соціально-психологічний підхід до проблеми бродяжництва дітей. Aктуальні проблеми практичної психологї: зб. наук. праџь. Херсон, 2006. С. 280-281.
} 
the structural integrity of the family and psychological - a violation of the system of interpersonal relationships, which leads to the development of an unfavorable psychological climate in the family. Psychological and structural deformations of the family lead to disharmonization of family relations and a negative atmosphere in the family. According to statistics, the 01.02.2018 year in Ukraine, more than 128 thousand incomplete and 333.187 large families who need social support ${ }^{12}$.

Divorce of parents is one of the most notable trends of family trouble at the moment. In single-parent families, mothers are forced to work fulltime in order to support the family, so the neglect of children in such families is higher than in full families, as well as the deviant behavior of children's behavior. Secondary families also often have a crisis, especially in the relationship between step-parents and foster children. Unhealthy emotional atmosphere in the family, conflict adversely affects the psyche of children, their social adaptation, leads to the child ignoring family values and alienating him from the family.

Research by I. Pesha shows that $46 \%$ of parents deprived of parental rights are chronic alcoholics, 34\% lead an immoral lifestyle, 17\% have committed crimes and are in places of detention. An asocial lifestyle of parents, different types of addiction, lead to moral degradation of parents. There are cases when the parents themselves force their children into begging or selling them criminal groups to participate in criminal activity. Having mastered the negative behavioral stereotypes, the teenager himself embarks on the path of crime and immorality ${ }^{13}$.

The abuse of alcohol by parents or other psychotropic substances often leads to various forms of violence against the child: physical, psychological or sexual. The study of R.M. Tkach testifies that ignoring children by their parents, a cruel attitude, form feelings of alienation and cause children to leave the family. Minors who are not satisfied with their life and family conditions are trying to change them. Going out on the street becomes a way to solve a specific problem, which is further consolidated into the strategy of adolescent behavior ${ }^{14}$.

\footnotetext{
12 Захист дітей, які потребують особливої уваги суспільства [Електронний ресурс]: статистичний збірник за 2017 рік. Державна служба статистики Украӥни; [відп. за вип. О.О. Кармазіна]. Київ: ДССУ, $2018.77 \mathrm{c}$.

${ }^{13}$ П'єша I. В. Соціальна допомога безпритульним та бездоглядним дітям, що надається закладами та організаціями різного підпорядкування. Украӥнський соиіум. 2007. № 5-6 (22-23). С. 49.

${ }_{14}$ Ткач Р.М. Соціально-психологічні чинники, що зумовлюють схильність дітей до бродяжництва. Актуальні проблеми психології: зб. наук. працьь Ін-ту психології ім. Г.С. Костюка АПН України. Київ, 2006. T. VIII ,ч. 8. С. 298-303.
} 
Among the neglected there are children who are brought up in seemingly prosperous families with a material condition. Most often, these are families with defects in upbringing, among which typical are families with authoritarian, custodial, condescending and chaotic upbringing styles. In an authoritarian family, too high demands are made on the child. Constant tension leads to the desire to get rid of this unpleasant state and can induce a teenager to go out. In a family with a custodial parenting style, a child is surrounded by excessive attention, but having experienced difficulties and not having the necessary skills to overcome them, such a child often falls under the influence of negative factors. An indulgent upbringing style is manifested in insufficient attention to the child by the parents, the child actually does not know the prohibition and restrictions on their part, perceiving this as a manifestation of indifference and emotional rejection. Subsequently, these children are not able to take into account the interests of other people, to establish strong emotional connections, they are not ready for restrictions and responsibilities. With chaotic styles there is no unified approach to education, there are no clearly defined requirements for the child, which deprives him of a sense of stability and also provokes social disadaptation ${ }^{15}$.

Thus, family dysfunction is a major factor in neglect of childrent, the separation of children from the family and their exit into the streets occurs primarily in socially disadvantaged and crisis families: incomplete, secondary or families with the wrong type of education.

\section{The impact of neglect on the process of socialization of teenagers}

Neglect is a crisis of childhood and is manifested in the social disadaptation of teenagers, varieties of deviant behavior: alcoholism, drug addiction, substance abuse, aggression, vagrancy, asocial lifestyle.

O. Selivanova considering neglect as a process of disadaptation distinguishes two phases:

1 - internal - the alienation of the individual from the institutional society;

2 - adaptation to an extra-institutional environment forms an external tendency in behavior that leads to a passive lowering to the "social bottom" and complicates the process of re-socialization.

\footnotetext{
15 Максимова Н.Ю. Психологія соціальної роботи із проблемними сім'ями: навч. посіб. Київ: ВПЦ “Київський університет”, 2017. 463 с.
} 
O. Selivanova notes that going out on the street can be like a meaningful behavioral act, especially if a neglected teenager is not actively willing to resist socialization and consciously demonstrates models of deviant behavior. In this case, neglect can be viewed as a model of behavior chosen by a teenager as a result of a conscious rejection of a situation that does not suit him in a family or in a social institution.

The reasons for leaving the teenager from outwardly prosperous family are ambivalent: on the one hand, the failure of actions expected from family members in terms of establishing a relationship with a teenager, and on the other - the inefficiency of its own activities on the adaptation to the institutional environment. These two trends may lead to the formation of internality relative to an extra-institutional environment. In this case, the behavioral potential of exit from the microsocium, which does not suit the teenager, is higher than the potential of unsuccessful attempts to adapt to this microsocium. The result of an attempt by a teenager to preserve the values of society can become a reticence, a withdrawal into the world of one's own fantasies, the emergence of neuroses, complexes and other disruptive reactions. In the case of seeking to challenge the values of society, it is possible to demonstrate an teenager antisocial behavior, which leads to more of its rejection by society, but it no longer has any meaning for him. It is the new personal experience that is valuable for him in this situation, whatever the moral and ethical coloring of this experience.

The behavior of a teenager in the process of adaptation to the street depends on what his previous development was, as well as on the quality of the tumors of previous secular periods. Adaptation to the "street" is always inconclusive, since the factors to be adjusted are constantly changing, the teenager's tension is increasing, the adaptation mechanisms are overstrained, the satisfaction of even basic needs is immediate and unwarranted. Thus, being on the street on their own initiative, the adolescent is faced with the problem of adapting to a low-structured, unstable extra-institutional environment.

The result of unsuccessful attempts at adaptation, as noted by O. Selivanova, is the emergence and development of "crises":

1) the crisis of indifference of the installation, when there is no longer attachment to the object (the institutions of society and their representatives); 
2) the crisis of unstructured world;

3) the crisis of emptiness that occurs when the social situation and leading activities change, experiencing the unpredictability, uncertainty of the future;

4) the crisis of promiselessness that arises when the connections of specific events with plans and real channels for their implementation are poorly represented in the mind ${ }^{16}$.

This is precisely the disadaptation of a neglected teenager as a state of internal dissonance, which is in a potential conflict between the attitudes of "Ego" (the desire to "prove to everyone the rightness") and direct experience (inability to carry out what was intended), which does not allow the teenager to restore integrity. Externality of behavior is characteristic of this state.

Going out on the street should be viewed not only as a distance from the family, but as a transfer of the teenager to the specific environment of vagrancy of minors, where there are customs, habits, norms and patterns of behavior. The teenager changes the subjects of identification, his moral and legal consciousness also changes. As a result of the influence of a negative microenvironment in a teenager, there is a destruction of positive values, instead of which antisocial norms and forms of behavior are assimilated. Thereby, neglected children sever any connection with society, fall as if in a social vacuum, remain outside society.

The dominant motive in the search for isolation is the need for understanding and affection. It is precisely the similarity of difficult characters that is the main reason for the unification of neglected teenagers. Communication with deviant peers correlates with the deficiency of social skills. The neglected teenager receives social recognition and selfaffirmation in the group of "similar", in such a group he feels "its", at the same time, all the troubles of life (hunger, cold, lack of hygiene, fear) begin to acquire attractive power, since the teenager believes that having defended his right to live outside of society, he established his potential for independent living in the street.

The reaction to the situation of chronic family distress, psychological violence, children form negativity or passive refusal to everything that is imposed on them as a habit to imitate any activity, at the same time, the

16 Селиванова О.А. Личностно значимые условия реинтеграции “уличного” подростка. Москва: Генезис, 2004. 239 с. 
ability for systematic efforts, which is important for independent living, is not formed. The teenagers becomes accustomed to the fact that little depends on him, resulting in an inability to plan his life, a low understanding of his ability to cope with problems and life difficulties.

The lack of positive communication with parents predetermines the development of inadequate communication with others, when protective situations of behavior dominate in conflict situations: inability to constructively solve a problem situation, outbreaks of aggression, and desire to shift responsibility to others. Disadaptation of the neglected children is manifested in the loss of social orientation of feelings, distrust of the social environment, social non-contact, inability to share their social roles, to establish friendly relations.

The study of N. Maksimova showed that the internal contradiction between the intensification of the teenager's negative emotions associated with the fact of domestic violence and the inability to express them in communication leads to a kind of "freezing" of emotions. At the same time, the development of the emotional sphere is inhibited, the formation of empathy does not occur, a peculiar emotional dullness is formed. This leads to the fact that in future adult life, such a person is not only unable to express his feelings, but also shy of them, trying to avoid situations related to the emotional area of life ${ }^{17}$.

Neglect negatively affect the homeostasis in the system of childsociety on the level of behavioral manifestations. The state of constant threat forms a catastrophic cognitive model of the world and the need for barriers when interacting in the form of aggressive reactions, avoidance of contact and violation of social norms. Studies show that children tend to vagrancy, have a specific formula of life style, based on distrust and caution in relation to people, which manifests itself in aggressive and hostile behavior.

Thus, the research of scientists shows that the consequence of the neglect of children is a violation of the process of their socialization, which is manifested in: - social disadaptation of minors; adaptation to the extrainstitutional environment, the inclusion of groups of asocial character and various types of deviant behavior.. Social factors, create the primary prerequisites for personal development of neglected teenagers. The lack of

\footnotetext{
${ }^{17}$ Максимова Н.Ю. Психологія соціальної роботи із проблемними сім'ями : навч. посіб. Київ: ВПЦ “Київський університет”, 2017. 463 с.
} 
positive emotional relationships with loved ones, the child's insecurity in the constancy and reliability of parents' love, their continued support and full acceptance is manifested in distortions of personal development, which in turn is an obstacle to the re-socialization of neglected teenagers.

\section{Psychological aspects of the re-socialization of neglected teenagers}

The problem of child neglect is typical of many countries, regardless of their level of wealth. Each country determines its own ways of overcoming this problem and providing social and psychological assistance to families who are in a difficult life situation. In western countries (Austria, Great Britain, Holland, Germany, USA, etc.), social services for working with children are developed. Support services for children and families provide patronage services, family psychotherapy, educational activities. Psychological correction centers provide assistance to families who have problems in dealing with children, advise them on psychological and pedagogical issues ${ }^{18}$.

Social Security abroad focuses on a normal stay of the child in the family, the identification of children who are abused by their parents. Social and legal protection of the child is provided taking into account the conditions of the social environment, and also provides for the provision of support to parents ${ }^{19}$.

In many Western countries (Austria, Germany, the US), there are multidisciplinary centers that provide psychotherapy to the children, the teenagers and their parents. Such centers act as "linear" structures of social services. For example:

- centers that specialize in helping to the teenagers who have difficulty communicating with their parents;

- centers that focus only on family support;

- centers that provide assistance to teenagers who are prone to alcohol and drugs.

"Linear" structures communicate with legal services, health organizations, social welfare services. Family support centers provide preventive activities and assist in critical conditions.

\footnotetext{
${ }^{18}$ Berg T., Vink C. Child and Youth Social Care Systems Abroad Lessons on strategies and systems from England, Germany, Norway and Sweden. The Netherlands Youth Institute 2009. P. 64.

${ }_{19}$ Кубіцький С. Історія соціальної роботи в зарубіжних країнах: навч. посібник. Київ: ДАКККІМ, 2009. $298 \mathrm{c}$.
} 
In Austria, children who have been subjected to violence in the family can be admitted to the temporary residence group at the regional crisis center. At the center, children continue to attend a regular school, and maintain relationships with their friends and parents, with whom work is also underway. The task of the Crisis Center - help the family overcome difficult circumstances ${ }^{20}$.

In Germany, widespread therapeutic and prophylactic Day care facilities for children. These are semi-stationary organizations in which children are from 8 to 17 hours. These centers make it possible to eliminate the lack of development in the child and correct behavior disorders, as well as conduct family psychotherapy.

For teenagers from the age of 16 who have left the family and have independent life experience, social dormitories are functioning in the United States. In these institutions, the principle - "adult" independent life of teenagers led by social workers. When a teenager is ready to leave the institution, they find separate housing for him to begin independent adulthood. But despite the fact that the teenager leaves the institution, social services helps him in solving life problems ${ }^{21}$.

Juvenile offenders, by court decision, are sent to closed rehabilitation centers. An example of a closed correctional institution is a Juvenile Center Hammargarden in Sweden, where at the same time contains no more than 24 teenagers and a staff of 76 persons (police officers, social workers, psychologists, psychotherapists, educators, doctors). The center represents a complex of houses in a suburban area: administrative house, school, kitchen, workshops, and five two-storeyed houses in which teenagers live. The barrier, as well as security, are absent on the territory of the center, however, walks, visits to schools, workshops, teenagers take place necessarily accompanied by an educator. School programs of the center are adapted to the level of knowledge and individual characteristics of the development of each teenager. Classes are held in groups of 3 teenagers and individually. In these institutions, teens are kept for up to 8 weeks. The task of the social service is to bring the teenager back to normal and return to the family ${ }^{22}$.

\footnotetext{
${ }^{20}$ Domestic Violence Perpetrator Programs in Europe, Part I: A survey of Current Practice. International Journal of Offender Therapy and Comparative Criminology. 2012. № 10. P. 56.

${ }^{21}$ Ковчина I.M., Вивчення досвіду соціально-правового захисту дітей та молоді у США та Канаді. Науковий часопис НПУ імені М.П. Драгоманова Серія 11. Соціологія. Соціальна робота. Київ 2007. C. $63-73$.

${ }^{22}$ Berg T., Vink C. Child and Youth Social Care Systems Abroad Lessons on strategies and systems from England, Germany, Norway and Sweden. The Netherlands Youth Institute. 2009. P. 33-41.
} 
The separation of the child from the family is used only in extreme cases, when the work of social services does not have a positive result, the child is removed from the family and transferred to a foster family. The leading trend in the social policy of the countries of Western Europe and America is the deinstitutionalization of the upbringing of children deprived of parental care. Boarding schools have almost ceased to exist, and in those that remained children who, for medical reasons, cannot live in foster care. In Austria, a well-developed system of adoption and foster the activities of institutions. Particular attention should be paid to the functioning of foster families in the In Great Britain and the activities of social services in relation to their support ${ }^{23}$.

The growing number of the neglected children in Ukraine at the end of the twentieth century, led to the need for reforms in the field of childhood policies and the implementation of urgent social and legal measures. Specialty institutions for children and adolescents have been established. Since 1997, a network of shelters for minors has been operating, the purpose of which is to provide social protection for children, their temporary placement (up to three months), status determination, and subsequent living arrangements. Since 2001, the reorganization of shelters in the centers of socio-psychological rehabilitation. At such a Center, neglected children can stay up to 9 months around the clock and another 12 months - in the day hospital. According to statistics from the Ministry of Social Policy on 1 January, 2018, in Ukraine there were 8 shelters and 75 centers for social and psychological rehabilitation for minors, which provide the first "emergency" assistance to the children ${ }^{24}$. Social rehabilitation centers solve the following tasks:

- preventive work on the prevention of neglect;

- provision of free social services to minors at social risk;

- identifying the causes of social maladjustment of minors;

- development of individual programs for the social rehabilitation of the children and the teenagers;

- provision of temporary stay of the neglected children and the teenagers;

- provide psychological assistance to child neglect;

\footnotetext{
23 Лактионова Г.М. Инновационные формы опеки детей: международный и национальный опыт. Київ: Науковий світ, 2011. $161 \mathrm{c.}$

24 Захист дітей, які потребують особливої уваги суспільства [Електронний ресурс] : статистичний збірник за 2017 рік. Державна служба статистики України; [відп. за вип. О.О. Кармазіна]. Київ: ДССУ, 2018. $77 \mathrm{c}$.
} 
- the solution of the question of the subsequent living arrangement of minors. Thus, the Social and Rehabilitation Centers make it possible to comprehensively solve the problems of correction and rehabilitation, which is aimed both at the child himself and at the society in which he or she is located ${ }^{25}$.

Crisis centers for social and psychological assistance for families began to function: - patronage of families at risk, - social support for families in the process of rehabilitating children with experience of deviant behavior.

The organization of preventive and remedial work of the center with the family is based on the following principles:

- the principle of timeliness provides for early detection of family distress, which helps to avoid extreme measures - depriving parents of parental rights;

- the principle of an individual approach in the choice of means of prevention and correction with each family;

- the principle of encouraging the family to self-help provides for the revitalization of its own internal resources for lifestyle changes ${ }^{26}$.

$\mathrm{N}$. Maximova notes that the re-socialization of the neglected children and teenagers provides for social, educational and psychological correction of deviant behavior. The condition for the socio-psychological assistance to the neglected children and teenagers is social control, which includes the efforts of the nearest social environment. At the same time, effective implementation of social control and the use of relevant effects is possible when analyzing not only the actions of a teenager, but also his attitude to his behavior ${ }^{27}$.

V. Orzhehovskaya suggests the following stages of the resocialization of the neglected children and teenagers:

- preparatory - removing children from the adverse conditions of the social environment, solving social and legal issues;

- organizational - conducting psychodiagnostics, development and implementation of psychotherapy programs, psychological and pedagogical correction, substantiation of an adequate educational program;

\footnotetext{
25 Система державних органів соціального захисту прав дітей-сиріт та дітей, позбавлених, батьківського піклування. Держава і право. [упоряд. О.М. Ноздріна]. Київ: Ін-т держави і права НАН України, 2006. Вип. 33. 270 с.

${ }^{26}$ Капська А.Й. Організація і технології соціальної роботи з дітьми вулиці. Київ: Інтернаціональний Союз. Ліга соціальних працівників України, 2004. 260 с.

${ }^{27}$ Максимова Н.Ю. Психологія соціальної роботи із проблемними сім'ями: навч. посіб. Київ: ВПЦ “Київський університет”, 2017. 463 с.
} 
- practical - creating and compensating for the child's social ties and conducting social and psychological monitoring of the child's condition $^{28}$.

The model proposed by Yu.M. Udovenko for the socio-psychological rehabilitation of children includes a network of Centers in which, taking into account the age of the child and the time he is on the street, work is being carried out in the following areas:

- social and psychological-pedagogical diagnostics;

- medical examination;

- preventive direction of social work;

- placement of children in the family;

- socio-psychological rehabilitation of the neglected children and teenagers.

The indicated directions of social and psychological assistance to the neglected children provide for the implementation of a differentiated approach based on taking into account the unfavorable experience of children and the violation of the main spheres of mental development. Work is being done not only with children, but also with parents, which makes it possible for the child to return to the family ${ }^{29}$.

A.. Kapska, N. Komarova offers four types of assistance Centers for the neglected children and teenagers, based on the degree of "immersion" of the child in street life and the level of disadvantage of his family:

1) Centers for the prevention of possible exit to the street children work with children who have problems, but they are still living at home;

2) Centers aimed at returning from the street children who have limited experience of street life, that is, they live both at home and on the street;

3) Centers aimed at creating social, psychological and pedagogical conditions for the return from the street of children who have sufficient experience of street life;

4) Day care centers for children who are limited in parental care ${ }^{30}$.

To ensure the temporary residence of the teenagers aged 15 to 23 years, social communities began to function in Ukraine. The goal of

\footnotetext{
28 Оржеховська В.М. Дитяча бездоглядність та безпритульність: історія, проблеми, пошуки: навч. посібник. Київ: Логос, 2004. 172 с.

29 Удовенко Ю.М. Система служб соціально-психологічної підтрімки дітей- жертв насильства (вітчизняний та зарубіжний досвід). Актуальні проблеми психології: зб. наук. праць Ін-ту психологї ім. Г. С. Костюка АПН Украӥни. Київ, 2006. Т. VIII, вип. 2. С. 336-342.

${ }^{30}$ Главник О., Комарова Н. Діти вулиці: хто вони і як їм допомогти. Київ: Главник, 2006. 112 с.
} 
social hostels is to create conditions for the social adaptation of the neglected teenagers, an external-individual form of education, assistance in obtaining a specialty and employment, preparation for independent living. The teenager can live there for three years, until he gets a profession. It will also give him the right to take up social housing registration and get social housing.

It should be noted that for the time of independence of Ukraine, a gradual transformation of the state system of custody of the children left without parents is carried out, family forms of education are being introduced.

Since of the 2008 year, the reform of the existing boarding schools began. The process of disaggregation of boarding schools continues, for example, the capacity of boarding schools has decreased from 200 pupils in the 2008 year to less than 50 children in the 2018 year. The initiated reforming processes provide of the children living conditions close to the family ones.

Over recent years there has been a tendency to adopt, 2925 of the children were adoptions in the 2017 year. However, there is no targeted psychological preparation of the children and families for adoption, therefore, there are cases of cancellation of adoption, for example, in the 2017 year there were 20 such cases ${ }^{31}$.

The most common form of placement of orphaned children is now in Ukraine is guardianship. At the beginning of the 2018 year, $72.8 \%$ of the total number of orphans and children deprived of parental care were in guardianship. It should be noted that the guardians are mostly elderly relatives. Therefore, it is necessary to develop and introduce mechanisms of social support, especially for families where the teenagers are brought up, in order to prevent them from going outside.

G. Bevz, I. Pesha note that of the foster family and the creation of the family-type orphanages is currently a form of addressing the problem of the neglect. The purpose of the foster family is the temporary custody of the children until their own parents are able to take care of them if it is impossible for the child to remain in the foster family ${ }^{32}$.

\footnotetext{
31 Захист дітей, які потребують особливої уваги суспільства [Електронний ресурс]: статистичний збірник за 2017 рік. Державна служба статистики України: [відп. за вип. О.О. Кармазіна]. Київ : ДССУ, $2018.77 \mathrm{c}$.

32 Пєша І.В Особливості функціонування дитячих будинків сімейного типу як сімейної форми опіки над дітьми-сиротами: Збірник наукових праць Херсонського державного пед. ун-ту. Херсон, 2006. Вип.13. С. 189.
} 
It should be noted that the number of children who are placed in foster families and family-type orphanages tends to increase. If in the 2009 year, 400 family-type orphanages functioned in Ukraine, by the end of the 2017 year it was 1019. The total number of children raised in foster homes and family-type orphanages at the beginning of 2018 was 12178 , which is $17 \%$ of the total number of orphans and children deprived of parental care.

However, at the stage of creation and functioning of the family-type orphanages and of the foster families there are many legal, material and psychological problems. According to G. Bevz, the necessary condition for successful adaptation of the child in a new family is mutual compliance of the role expectations of the child and adoptive the parents, taking into account the influence of the child's previous life experience on the identification process with the family. The neglected children in a new environment tend to the same identity, which provoke conflicts and withdrawal from the new family. It was the lack of psychological assistance to adoptive parents and children during the period of the child's adaptation to life in a new family that led to the emergence of the problem of returning children from foster families to boarding schools, from where they again run into the street ${ }^{33}$.

It should be noted that not every neglected child can effectively adapt to the situation in a new family, it depends on the type of neglect, the degree of maladjustment and the specifics of personality deformation, this must be considered when setting up a neglected child in a foster family.

Thus, currently under a lot of activities to prevent and overcome the neglect of children: a legal framework has been created for working with crisis families and the social protection of the children in difficult life situations; there is a network of centers for social and psychological rehabilitation for the minors.

\section{CONCLUSIONS}

Neglect is the complex socio-psychological phenomenon that arises in the interpersonal social-psychological system "children-parents" and manifests itself in the destruction of the emotional connection between the child and the parents, in the absence of care, positive influence on the part of the parents, and lack of control over the behavior and activities of the children. The emergence and distribution of the category of the neglected children is associated with the political and economic development of the

\footnotetext{
${ }^{33}$ Бевз Г.М. Прийомні сім’ї: оцінка створення, функціонування та розвитку. Київ: Главник, 2006. 112 с.
} 
country, the functioning of its social and legal system, and also depends on the degree of development of public morality and social protection of the family institution.

The alienation of the children from the family and their exit to the street primarily occurs in the dysfunctional families and the crisis families. Features of the social situation of development determine the specificity of socialization and the formation of the personality of the neglected children and teenagers. It should be noted that in the category of street children can get both from disadvantaged families, as well as from external stable families and children who do not have families. The definition of categories of the neglected children creates the prerequisites for a differentiated approach in providing them with social and psychological assistance and identifying ways of their re-socialization.

Social services focus on the organization of the work to improve the conditions of the family upbringing in families that belong to the social risk group. Currently, there is a certain system of correctional and rehabilitation work with minors who are in a difficult life situation. This system includes various state and public organizations, multidisciplinary centers, which, within their competence, carry out measures for the prevention and overcoming of neglect among minors.

\section{SUMMARY}

In the article it was considered the actual social problem of child neglect. On the basis of theoretical analysis of the psychological literature it was refined the concept of «street children» «homeless children» and «neglect children». It was found that the neglect is the weakening or lack of supervision of the child by the parents that can be one of the stages of personality desocialization and the transition to the state of homelessness, which is characterized by complete separation of the minor from the family and is connected to the loss of permanent residence. It is set that not only the antisocial families, but also the families with the conflict relations or with the wrong type of education are the factors of child's neglect. The attention to the consequence of the children' neglect is drawn to violation of the process of socialization, which is manifested in the social disadaptation and in the various types of deviant behavior of minors. It was concluded that it is necessary to implement the differentiated approach in the provision of socio-psychological assistance to the neglect children and to identify the ways of their resocialization. 


\section{REFERENCES}

1. Бартол К. Психология криминального поведения. СПб.: прайм-ЕВРОЗНАК, 2004. 352 с.

2. Бевз Г.М. Прийомні сім’ї: оцінка створення, функціонування та розвитку. Київ: Главник, 2006. 112 с.

3. Berg T., Vink C. Child and Youth Social Care Systems Abroad Lessons on strategies and systems from England, Germany, Norway and Sweden. The Netherlands Youth Institute. 2009. P. 64.

4. Главник О., Комарова Н. Діти вулиці: хто вони і як їм допомогти. Київ: Главник, 2006. 112 с.

5. Горобець I. В. Механізми державного управління у сфері протидії дитячій безпритульності та бездоглядності в Україні: автореф. дис. на здобуття наук. ступеня канд. держ. упр.: 25.00 .02 «Механізми державного управління». Івано-Франківськ, 2012. С. 13.

6. Domestic Violence Perpetrator Programs in Europe, Part I: A survey of Current Practice. International Journal of Offender Therapy and Comparative Criminology. 2012. № 10. P. 56.

7. Захист дітей, які потребують особливої уваги суспільства [Електронний ресурс]: статистичний збірник за 2017 рік. Державна служба статистики України [відп. за вип. О.О. Кармазіна]. Київ: ДССУ, 2018. 77 с.

8. Капська А.Й. Організація і технології соціальної роботи 3 дітьми вулиці. Київ: Інтернаціональний Союз. Ліга соціальних працівників України, 2004. 260 с.

9. Ковчина I.M., Вивчення досвіду соціально-правового захисту дітей та молоді у США та Канаді. Науковий часопис НПУ імені М.П. Драгоманова Серія 11. Соціологія. Соціальна робота. Київ, 2007. C. $63-73$.

10. Кубіцький С. Історія соціальної роботи в зарубіжних країнах: навчальний посібник. Київ: ДАКККіМ, 2009. 298 с.

11. Лактионова Г.М. Инновационные формы опеки детей: международный и национальный опыт. Київ: Науковий світ, 2011. 161 с.

12. Максимова Н.Ю. Психологія соціальної роботи із проблемними сім'ями: навч. посіб. Київ: ВПЦ "Київський університет", 2017. 463 с.

13. Мітіна С.В. Соціальні чинники бездоглядності підлітків. Вісник Київського національного університету імені Тараса Шевченка Київ, 2013. № 1(7). С. 74-77. 
14. Мустаева Ф.А. Основы профилактики безнадзорности и беспризорности несовершеннолетних. Москва, 2003. 456 с.

15. Оржеховська В.М. Дитяча бездоглядність та безпритульність: історія, проблеми, пошуки: навч. посібник. Київ: Логос, 2004. 172 с.

16. Пєша I.В. Особливості функціонування дитячих будинків сімейного типу як сімейної форми опіки над дітьми-сиротами. Збірник наукових праць Херсонського державного пед. ун-ту. Херсон, 2006. Вип. 13. С. 189.

17. П'єша I.B. Соціальна допомога безпритульним та бездоглядним дітям, що надається закладами та організаціями різного підпорядкування. Український соичумм. 2007. № 5-6 (22-23). С. 49.

18. Про забезпечення організаційно-правових умов соціального захисту дітей-сиріт та дітей, позбавлених батьківського піклування. Закон України (зі змінами від 08.02.2018 року) Відомості Верховної Ради України. 2005. № 6. Ст. 147.

19. Реалізація конвенції ООН права дитини в Україні: досягнення, проблеми, перспективи (за період 2009-2016 р.p.). Державна доповідь про становище дітей в Украӥні. Київ: Міністерство соціальної політики України, 2016. 164 с.

20. Селиванова О.А. Личностно значимые условия реинтеграции „уличного” подростка. Москва: Генезис, 2004. 239 с.

21. Система державних органів соціального захисту прав дітейсиріт та дітей, позбавлених, батьківського піклування. Держава $i$ право. [упоряд. О.М. Ноздріна]. Київ: Інститут держави і права НАН України, 2006. Вип. 33. 270 с.

22. Ткач Р.М. Соціально-психологічні чинники, що зумовлюють схильність дітей до бродяжництва. Актуальні проблеми психологї: збірник наук. праць Ін-ту психології ім. Г.С. Костюка АПН України. Київ, 2006. T. VIII, ч. 8. С. 298-303.

23. Удовенко Ю.М. Система служб соціально-психологічної підтрімки дітей-жертв насильства (вітчизняний та зарубіжний досвід). Актуальні проблеми психологї: збірник наук. пращь Ін-ту психології ім. Г.С. Костюка АПН України. Київ, 2006. Т. VIII, вип. 2. С. 336-342.

24. Юрченко Т.А. Соціально-психологічний підхід до проблеми бродяжництва дітей. Актуальні проблеми практичної психології: зб. наук. працьь. Херсон, 2006. С. 280-281. 
Information about the author: Mitina S. V. Associate Professor at the Department of Psychology and Pedagogy of the V. I. Vernadsky Taurida National University 33, Ivana Kydri str., Kyiv, 01042, Ukraine mitina.svetlana68@gmail.com Researcher ID: G-7268-2017 ORCID: 0000-0001-9520-0272 